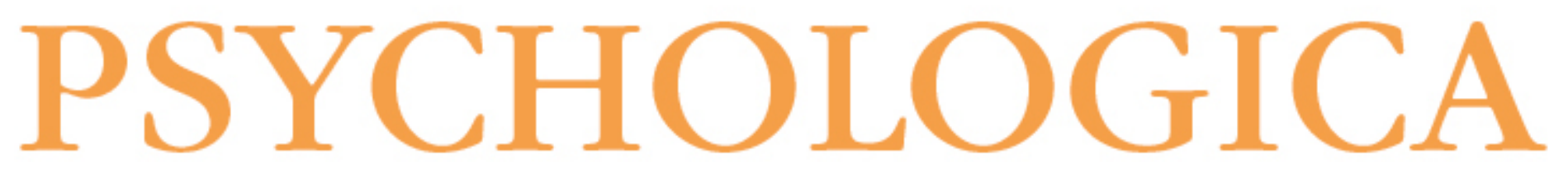

Psychometric properties of the schedule of growing skills II: portuguese version

Varajidás, Carla Afonso; Machado, Magda; Mota, Maria Paula; Martins,

Autor(es): $\quad$ Rui; Lisboa, Maria Carmo; Soares, Isabel; Sousa, Susana; Leitão, José Carlos

Publicado por: Imprensa da Universidade de Coimbra

URL

persistente: URI:http://hdl.handle.net/10316.2/42335

DOI: $\quad$ DOI:https://doi.org/10.14195/1647-8606_60-1_1

Accessed : $\quad$ 26-Apr-2023 09:49:58

A navegação consulta e descarregamento dos títulos inseridos nas Bibliotecas Digitais UC Digitalis, UC Pombalina e UC Impactum, pressupõem a aceitação plena e sem reservas dos Termos e Condições de Uso destas Bibliotecas Digitais, disponíveis em https://digitalis.uc.pt/pt-pt/termos.

Conforme exposto nos referidos Termos e Condições de Uso, o descarregamento de títulos de acesso restrito requer uma licença válida de autorização devendo o utilizador aceder ao(s) documento(s) a partir de um endereço de IP da instituição detentora da supramencionada licença.

Ao utilizador é apenas permitido o descarregamento para uso pessoal, pelo que o emprego do(s) título(s) descarregado(s) para outro fim, designadamente comercial, carece de autorização do respetivo autor ou editor da obra.

Na medida em que todas as obras da UC Digitalis se encontram protegidas pelo Código do Direito de Autor e Direitos Conexos e demais legislação aplicável, toda a cópia, parcial ou total, deste documento, nos casos em que é legalmente admitida, deverá conter ou fazer-se acompanhar por este aviso.

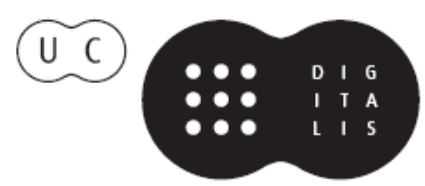


vOLUME
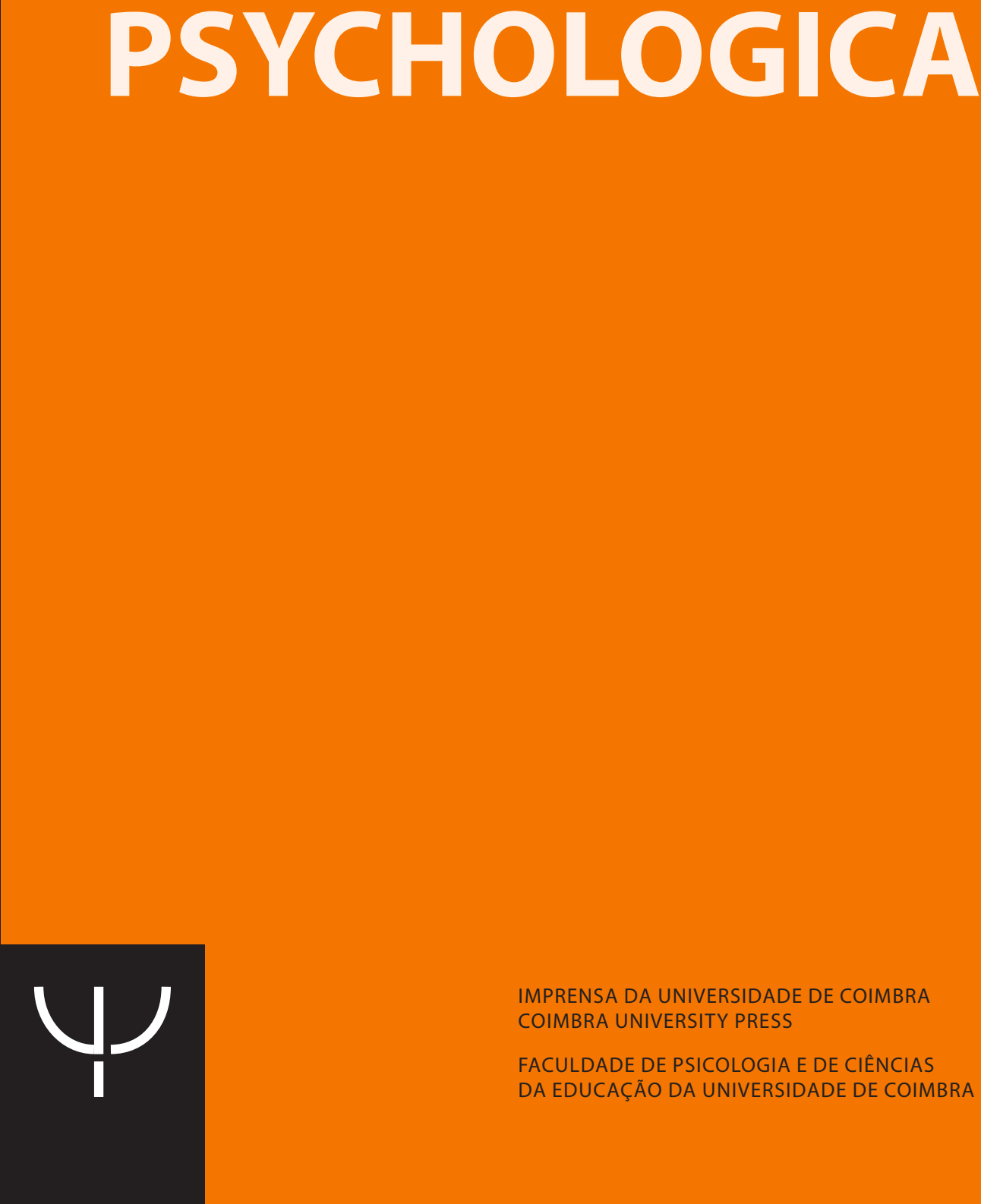

IMPRENSA DA UNIVERSIDADE DE COIMBRA

COIMBRA UNIVERSITY PRESS

FACULDADE DE PSICOLOGIA E DE CIÊNCIAS

DA EDUCAÇÃO DA UNIVERSIDADE DE COIMBRA 


\title{
Psychometric properties of the schedule of growing skills II: Portuguese version
}

\author{
Carla Afonso Varajidás ${ }^{1}$, Magda Machado $^{2}$, Maria Paula Mota ${ }^{3}$, \\ Rui Martins ${ }^{4}$, Maria Carmo Lisboa ${ }^{5}$, Isabel Soares ${ }^{6}$, Susana Sousa ${ }^{7}$ e \\ José Carlos Leitão ${ }^{8}$
}

\begin{abstract}
The second version of the Schedule of Growing Skills (SGS-II) was standardized using a sample of 348 UK children, ages 0 to 5 years. It examined ten psychomotor development areas in 14 age ranges. The Portuguese version of SGS-II was published in 2003, re-edited in 2011, and re-published in 2012, but its psychometric properties remained untested. The aim of this study was to evaluate the psychometric properties of the Portuguese version of SGS-II, comparing them with the results of the UK version.

A sample of 364 Portuguese children, 193 boys and 172 girls, with an average age of 34.45 months $( \pm 18.62)$ was assessed with the SGS-II. The results have shown suitable psychometric properties of the SGS-II Portuguese version, adequate for the screening of children development. The internal consistency coefficients ranged from adequate
\end{abstract}

1 Universidade de Trás-os-Montes e Alto Douro. Research in Education and Community Intervention - RECI. Email: carlafonso@utad.pt

2 Editora Hogrefe - General Manager. Email: magda.machado@hogrefe.pt

3 Universidade de Trás-os-Montes e Alto Douro. Centro de Investigação em Desporto, Saúde e Desenvolvimento Humano

- CIDESD. Email: mpmota@utad.pt

4 Faculdade de Motricidade Humana - Universidade de Lisboa. Email: rmartins@fmh.ulisboa.pt

5 Centro Hospitalar de Trás-os-Montes e Alto Douro. Email: carmoqlisboa@hotmail.com

6 Centro Hospitalar de Trás-os-Montes e Alto Douro. Email: ILSOARES@chtmad.min-saude.pt

7 Centro Hospitalar de Trás-os-Montes e Alto Douro. Email: susanasous@hotmail.com

8 Universidade de Trás-os-Montes e Alto Douro. Centro de Investigação em Desporto, Saúde e Desenvolvimento Humano

- CIDESD. Email: jcleitao@utad.pt

Artigo recebido a 18-04-2014 e aprovado a 14-12-2016.

PSYCHOLOGICA VOLUME 60 № $1 \cdot 2017$ 
to excellent ( $\geq .7)$ and similar correlation results among the scale's versions (English and Portuguese) were positive, high, and significant.

Keywords: psychomotor development; children; measures; psychometric properties; reliability

\section{Propriedades psicométricas da escala de avaliação das competências no desenvol- vimento infantil II - schedule of growing skills II (SGS II): Versão Portuguesa}

\section{Resumo}

A segunda versão da Escala de Avaliação das Competências no Desenvolvimento Infantil Schedule of Growing Skills (SGS-II) foi padronizada no Reino Unido, utilizando uma amostra de 348 crianças, dos 0 aos 5 anos. A escala avalia dez áreas de desenvolvimento psicomotor em 14 faixas etárias. A versão em Português da SGS-II foi publicada em 2003, reeditada em 2011 e em 2012, sem avaliação das qualidades psicométricas. O objetivo deste estudo foi avaliar as qualidades psicométricas da versão portuguesa, comparando-as com os resultados da versão original. Uma amostra de 364 crianças portuguesas, 193 meninos e 172 meninas, com idade média de 34.45 meses $( \pm 18.62)$ foi avaliada com a SGS-II. Os resultados mostraram que a versão portuguesa da SGS-II tem propriedades psicométricas adequadas ao rastreio do desenvolvimento infantil, com coeficientes de consistência interna adequados e excelentes $(\geq 0.7)$, sendo semelhantes aos obtidos a partir dos estudos de confiabilidade realizados na versão inglesa.

Palavras-chave: desenvolvimento psicomotor; crianças; avaliação; propriedades psicométricas; fiabilidade

\section{INTRODUCTION}

Psychomotor development is a dynamic and continuous process that relies on the interaction of genetics and environment factors (Fonseca, 2005; Matos, 2009; Direção-Geral da Saúde, 2013). Growth and development are excellent markers of a child's general well-being and are crucial for health over the life span (Anderson et al., 2003; Clayden \& Lissauer, 2017). As children grow changes in posture, locomotive, manipulative, visual, hearing, language, speech, cognitive 
and social competences are expected. Despite some variation exists in the rate of these changes, significant deviation could reflect problems in the psychomotor development. Concerning these occurrences, the American Academy of Pediatrics recommends that all children have integrated developmental surveillance and screening programs (Committee on Children with Disabilities, 2001; LaRosa \& Glascoe, 2009) to ensure early intervention that might minimize the negative consequences of delayed or disordered development.

Some studies suggest that approximately $71 \%$ of psychomotor development assessments are made based solely on clinical judgment, without using any standardized screening tool, and that this might compromise the results' accuracy. Of these, $50 \%$ use informal checklists, and only $23 \%$ use validated screening instruments (Sand et al., 2005).

Psychomotor development screening should be a systematic process that enables the early identification of possible delays or disorders. To this end, the instrument used must be valid and reliable, and should take into account all relevant areas of development in order to provide accurate and measurable results. Indeed, these kinds of instruments should be culturally adapted to avoid misunderstanding results (Early Head Start National Resource Center, 2001). Moreover, the instrument should also be quick and easy to use.

There are several instruments that provide information about the quality of children psychomotor development (Bellman et al., 2012; Frankenburg et al., 1990). The results of the psychometric properties of the Schedule of Growing Skills II (SGS-II) (Bellman et al., 2012) have shown that this is a valid and reliable developmental screening tool (Bellman, Lingam, \& Aukett, 1996). The final output of this scale is expressed in a development age in nine different areas (Passive Posture, Active Posture, Locomotion, Manipulation, Visual, Hearing and Language, Speech and Language, Interactive Social, Self-Care Social and Cognition) that vary according to child's chronological age (Bellman et al., 2012; Shevell et al., 2003). According to the results, a child may be classified as having an adequate or delayed development. English version of SGS-II reliability was calculated according to the Cronbach alpha procedures with a sample size of 348 children (Bellman et al., 2012). The majority of the scales revealed high reliability scores, with lower values matched in "Passive Posture Control" (.61) and in "Active Postural Control" (.88). The researchers explained these lower values of Cronbach alpha owing to the small age range (0-6 months and 0-12 months, respectively).

The Portuguese version of SGS-II was first published in 2003, reedited in 2011 and published afterward in 2012. As far as it is known, the translation and adaptation to Portuguese was in charge of Rocha, Machado and Ferreira with 
the supervision of Andrada and Folha, (Bellman et al., 2012), two paediatric specialists (doctor and nurse, respectively). However, until now, it has not been standardized. Since an instrument's validity and reliability can be affected by several factors, among them cultural differences and the quality of the translation (Early Head Star National Resource Center, 2001) the purpose of this study was to analyse the Portuguese version of SGS-II's psychometric properties (Bellman, Lingam, \& Aukett, 2012). The SGS-II validity is an important issue to ensure an accurate screening of atypical situations, according to the child's psychomotor profile, which may enable an early intervention.

\section{METHODS}

The sample included 364 children from birth to 5 years old (34.44 \pm 18.63$), 193$ boys and 171 girls, assessed at two health units of the Child Health Surveillance consultation and a day-care centre. Every child in the sample met the following inclusion criteria: i) having the authorization of the health-care unit's director; ii) being from 0 to 60 months old; iii) having an informed consent signed by the child's primary caregiver and iv) absent of present diagnostic of developmental disorders. All participants were informed in advance about all procedures and risks to which they would be subjected during the tests, and signed a consent in accordance with the Helsinki Declaration (UNESCO, 2006).

\section{MATERIALS}

Developmental screening was carried out using the Portuguese version of SGS-II (2012). The main purpose of this scale is to measure child development with a simple and reliable procedure suitable for screening atypical situations. Moreover, this scale can also be used to follow changes in a child development at different moments of evaluation.

SGS-II includes a total of 179 items that examines nine key areas (scales) that vary according to the child's age: i) Passive Posture (PP: 0-6 months), items 1 to 9; ii) Active Posture (AP: 0-12 months), items 10 to 21; iii) Locomotor (LO: 9-60 months), items 22 to 41; iv) Manipulative (MA: 0-60 months), items 42 to 69; v) Visual (VI: 0-60 months), items 70 to 89; vi) Hearing and Language (HL: 0-60 months), items 90 to 110; vii) Speech and Language (SL: 0-60 months), 
items 111 to 132; viii) Interactive Social (IS: 0-60 months), items 133 to 156; ix) Self-Care Social (SC: 6-60 months), items 157 to 179 divided into 14 age bands. It is also possible to assess a cognitive area (COG: 3-60 months) using relevant items of the nine key areas (sum of items 55 to 69 of manipulative area, plus 76 to 88 of visual area, plus item 143,144,150,152, 155 and 156 of interactive social area).

Reliability studies of the original version of SGS-II used a sample of 348 children. Table 1 shows the results of the internal consistency study using Cronbach's alpha coefficient.

Table 1

Internal Consistency Coefficients of SGS-II's UK Version - Cronbach's alpha

\begin{tabular}{lccccc}
\hline \multicolumn{1}{c}{ Scales/Key Areas } & $\boldsymbol{\alpha}$ & Max & Mean & SD & SE $_{\mathbf{M}}$ \\
\hline Passive Posture & .61 & 9 & 8.93 & 0.40 & 0.25 \\
Active Posture & .88 & 12 & 11.44 & 1.64 & 0.57 \\
Locomotor & .96 & 20 & 12.79 & 6.19 & 1.24 \\
Manipulative & .96 & 28 & 18.54 & 7.67 & 1.53 \\
Visual & .92 & 20 & 15.11 & 4.51 & 1.28 \\
Hearing and Language & .93 & 21 & 13.84 & 5.45 & 1.44 \\
Speech and Language & .95 & 22 & 14.70 & 6.39 & 1.43 \\
Interactive Social & .95 & 24 & 17.75 & 6.14 & 1.37 \\
Self-Care Social & .93 & 23 & 14.82 & 6.17 & 1.63 \\
Cognitive & .97 & 34 & 20.13 & 11.20 & 1.94 \\
\hline
\end{tabular}

$\mathrm{n}=348$

Assessments began after the Ethics Commission of the Trás-os-Montes e Alto Douro's Hospital approval of this study. Each child was assessed individually, and parents were encouraged to remain with their child in the room to provide confidence and security. The items were administered according to SGS-II's User's Guide instructions, by a psychomotor therapeutic and a kindergarten teacher, both well-trained persons in the procedures of this scale. Whenever the results of the examination suggested a possible developmental delay or disorder, the child was referred to a specialist for further assessment.

Statistical analysis was carried out in SPSS version 20.0, and the significance level was set at .05. Data distribution analysis was made using Kolmogorov-Smirnov test. Afterwards, the basic features of the data were studied, and central tendency measures and dispersion measures were computed for the numerical variables. For the categorical variables, percentages and frequencies were calculated. Internal consistency was assessed using Cronbach's alpha. Spearman's rho coefficient was used to analyse correlations between the scales. 


\section{RESULTS}

Regarding the sample distribution according to age, there are more boys than girls in all age groups (Table 2) except in the two younger ones.

Table 2

Portuguese Sample Distribution by Age Group (Years), Gender, and Age in Months

\begin{tabular}{|c|c|c|c|c|c|}
\hline \multirow[b]{2}{*}{ Age group } & \multirow[b]{2}{*}{$\mathbf{N}$} & \multirow{2}{*}{$\begin{array}{c}\text { Age } \\
\text { Mean } \pm S D \text { (months) }\end{array}$} & \multirow{2}{*}{$\begin{array}{c}\text { Amplitude } \\
\text { (months) }\end{array}$} & \multicolumn{2}{|c|}{ Gender } \\
\hline & & & & $\begin{array}{c}\text { Male } \\
\text { N (\%) }\end{array}$ & $\begin{array}{l}\text { Female } \\
\mathrm{N}(\%)\end{array}$ \\
\hline$<1$ year old & 54 & $5.89 \pm 3.66$ & $1-11$ & $21(38.9 \%)$ & $33(61.1 \%)$ \\
\hline 1 year old & 54 & $16.93 \pm 3.64$ & $12-23$ & $26(48.1 \%)$ & $28(51.9 \%)$ \\
\hline 2 years old & 73 & $28.47 \pm 3.29$ & $24-35$ & $42(57.5 \%)$ & $31(42.5 \%)$ \\
\hline 3 years old & 71 & $41.51 \pm 3.68$ & $36-47$ & $41(57.7 \%)$ & $30(42.3 \%)$ \\
\hline 4 years old & 73 & $52.66 \pm 3.66$ & $48-59$ & $39(53.4 \%)$ & $34(46.6 \%)$ \\
\hline 5 years old & 39 & $62.44 \pm 3.26$ & $60-71$ & $24(61.5 \%)$ & $15(38.5 \%)$ \\
\hline
\end{tabular}

The results of the internal consistency studies of the Portuguese version of SGS-II can be seen in Table 3.

Table 3

Descriptive Analysis (Mean and Standard Deviation, SD), Internal Consistency, and Standard Error of SGS-II's Portuguese Version

\begin{tabular}{lccccc}
\hline \multicolumn{1}{c}{ Scales/Key Areas } & $\boldsymbol{\alpha}$ & Max & Mean & SD & SE $_{\mathbf{M}}$ \\
\hline Passive Posture & .81 & 9 & 4.52 & 2.62 & 0.457 \\
Active Posture & .87 & 12 & 6.46 & 4.07 & 0.497 \\
Locomotor & .90 & 20 & 13.17 & 4.66 & 0.257 \\
Manipulative & .83 & 28 & 17.87 & 8.03 & 0.421 \\
Visual & .84 & 20 & 15.09 & 5.27 & 0.276 \\
Hearing and Language & .78 & 21 & 13.98 & 5.59 & 0.294 \\
Speech and Language & .81 & 22 & 14.03 & 6.15 & 0.322 \\
Interactive Social & .93 & 24 & 17.65 & 6.40 & 0.335 \\
Self-Care Social & .91 & 23 & 15.05 & 6.30 & 0.342 \\
Cognitive & .80 & 34 & 20.49 & 9.81 & 0.535 \\
\hline
\end{tabular}

$\mathrm{n}=364$

The Portuguese version of SGS-II revealed results ranging from "adequate" for the Hearing and Language scale to "excellent" for all of the other scales.

In regard to the correlations between scales, the results have shown that all of them were strongly and positively correlated. 
Regarding the first age group (i.e., less than one year old), all the results were positive and significant (Table 4$)$.

Table 4

Correlations Between SGS-II's Scales: Age Group below 1 Year's Old

\begin{tabular}{|c|c|c|c|c|c|c|c|c|c|c|}
\hline & PP & AP & LO & MA & VI & HL & SL & SI & SC & COG \\
\hline PP & 1.0 & & & & & & & & & \\
\hline AP & $.93^{\star *}$ & 1.0 & & & & & & & & \\
\hline LO & .87 & $.56^{\star}$ & 1.0 & & & & & & & \\
\hline MA & $.59^{* *}$ & $.84^{* *}$ & $.61^{* *}$ & 1.0 & & & & & & \\
\hline VI & $.84^{\star *}$ & $.89^{* *}$ & $.61^{\star *}$ & $.92^{\star \star}$ & 1.0 & & & & & \\
\hline HL & $.91^{\star *}$ & $.91^{\star *}$ & $.47^{\star}$ & $.83^{\star *}$ & $.88^{\star *}$ & 1.0 & & & & \\
\hline SL & $.69^{* *}$ & $.89^{* *}$ & $.79^{\star *}$ & $.87^{\star *}$ & $.89^{\star *}$ & $.87^{\star *}$ & 1.0 & & & \\
\hline SI & $.73^{\star *}$ & $.90^{\star *}$ & $.77^{\star *}$ & $.90^{\star *}$ & $.90^{\star *}$ & $.89^{\star *}$ & $.90^{\star *}$ & 1.0 & & \\
\hline SC & $.91^{\star *}$ & $.85^{\star *}$ & $.87^{\star *}$ & $.78^{\star *}$ & $.76^{\star *}$ & $.71^{\star *}$ & $.79^{\star *}$ & $.81^{\star \star}$ & 1.0 & \\
\hline COG & .83 & $.60^{* *}$ & $.80^{* *}$ & $.67^{\star *}$ & $.68^{\star *}$ & $.48^{\star *}$ & $.76^{* *}$ & $.74^{\star *}$ & $.76^{\star *}$ & 1.0 \\
\hline
\end{tabular}

The highest correlation coefficient was obtained between the Active Posture scale and the Passive Posture scale $(.93, p \leq .01)$. The lowest correlation was obtained between the Locomotor scale and the Active Posture scale $\left(.56^{*}\right)$.

Regarding the one-year-old age group, almost all the variables were significantly correlated except the Active Posture scale that correlated only the Cognition area $(.73, p \leq .01)$ (Table 5). Correlations with the Passive Posture scale were not computed, since this scale is restricted to the 0-6 months' age group.

Table 5

Correlations Between SGS-II's Scales: Age Group of 1 Year's Old

\begin{tabular}{|c|c|c|c|c|c|c|c|c|c|}
\hline & CPA & LO & MA & VI & AudLing & FaLing & IS & AP & COG \\
\hline CPA & 1.0 & & & & & & & & \\
\hline LO & .51 & 1.0 & & & & & & & \\
\hline MA & .24 & $.71^{\star *}$ & 1.0 & & & & & & \\
\hline VI & .47 & $.66^{* *}$ & $.61^{\star *}$ & 1.0 & & & & & \\
\hline AudLing & .31 & $.61^{\star *}$ & $.65^{\star \star}$ & $.85^{\star \star}$ & 1.0 & & & & \\
\hline FaLing & .41 & $.59^{* *}$ & $.61^{\star *}$ & $.67^{* *}$ & $.73^{\star *}$ & 1.0 & & & \\
\hline IS & .51 & $.65^{\star *}$ & $.75^{\star *}$ & $.61^{\star *}$ & $.65^{\star *}$ & $.59^{\star *}$ & 1.0 & & \\
\hline AP & .30 & $.77^{\star *}$ & $.70^{\star *}$ & $.71^{* *}$ & $.63^{* *}$ & $.66^{* *}$ & $.58^{* *}$ & 1.0 & \\
\hline COG & $.73^{* *}$ & $.78^{\star *}$ & $.88^{\star \star}$ & $.79^{* *}$ & $.77^{\star \star}$ & $.63^{\star *}$ & $.82^{\star *}$ & $.78^{\star \star}$ & 1.0 \\
\hline
\end{tabular}

Note: ${ }^{*} \mathrm{p} \leq .05{ }^{* *} \mathrm{p} \leq .01$ 
Since the Passive Posture and Active Posture scales do not cover older age groups, correlations with other scales were not calculated for the rest of the age groups.

As for the two-year-old age group, correlations between all scales were significant (Table 6).

Table 6

Correlations Between SGS-II's Scales: Age Group of 2 Years' Old

\begin{tabular}{|c|c|c|c|c|c|c|c|c|}
\hline & LO & MA & VI & AudLing & FaLing & IS & AP & COG \\
\hline LO & 1.0 & & & & & & & \\
\hline MA & $.52^{\star *}$ & 1.0 & & & & & & \\
\hline VI & $.47^{\star \star}$ & $.74^{\star *}$ & 1.0 & & & & & \\
\hline AudLing & $.45^{\star *}$ & $.70^{\star *}$ & $.75^{\star *}$ & 1.0 & & & & \\
\hline FaLing & $.64^{\star *}$ & $.57^{\star \star}$ & $.58^{\star *}$ & $.65^{\star *}$ & 1.0 & & & \\
\hline IS & $.50^{\star \star}$ & $.59^{\star *}$ & $.51^{\star \star}$ & $.57^{\star \star}$ & $.47^{\star *}$ & 1.0 & & \\
\hline AP & $.48^{\star \star}$ & $.58^{\star *}$ & $.43^{\star *}$ & $.46^{\star *}$ & $.47^{\star \star}$ & $.44^{\star \star}$ & 1.0 & \\
\hline COG & $.55^{\star \star}$ & $.85^{\star *}$ & $.84^{* *}$ & $.81^{\star *}$ & $.68^{\star *}$ & $.62^{\star *}$ & $.56^{\star *}$ & 1.0 \\
\hline
\end{tabular}

The Self-Care Social scale and the Visual scale had the lowest result $(.43, p \leq .01)$. The Cognition and Manipulative scales had the highest correlation $(.85, p \leq .01)$.

For the three-year-old age group, all correlations were significant (Table 7 ).

Table 7

Correlations Between SGS-II's Scales: Age Group of 3 Years' Old

\begin{tabular}{|c|c|c|c|c|c|c|c|c|}
\hline & LO & MA & VI & AudLing & FaLing & IS & AP & COG \\
\hline LO & 1.0 & & & & & & & \\
\hline MA & $.52^{\star \star}$ & 1.0 & & & & & & \\
\hline VI & $.44^{\star *}$ & $.41^{\star *}$ & 1.0 & & & & & \\
\hline AudLing & $.47^{* *}$ & $.65^{\star *}$ & $.35^{\star *}$ & 1.0 & & & & \\
\hline FaLing & $.48^{* *}$ & $.67^{\star *}$ & $.36^{\star *}$ & $.61^{\star *}$ & 1.0 & & & \\
\hline IS & $.44^{* *}$ & $.63^{* *}$ & $.42^{\star \star}$ & $.64^{\star *}$ & $.67^{\star *}$ & 1.0 & & \\
\hline AP & $.43^{* *}$ & $.52^{\star *}$ & $.29^{\star *}$ & $.56^{\star *}$ & $.55^{\star *}$ & $.46^{\star *}$ & 1.0 & \\
\hline COG & $.58^{\star *}$ & $.86^{* *}$ & $.53^{\star \star}$ & $.72^{\star *}$ & $.67^{\star *}$ & $.69^{* *}$ & $.52^{* *}$ & 1.0 \\
\hline
\end{tabular}

The Cognition and Manipulative scales have the highest correlation $(.86, p \leq .01)$. 
In regard to the four-year-old age group, correlations between the scales also show statistically significant results (Table 8 ).

Table 8

Correlations Between SGS-II's Scales: Age Group of 4 Years' Old

\begin{tabular}{|c|c|c|c|c|c|c|c|c|}
\hline & LO & MA & VI & AudLing & FaLing & IS & AP & COG \\
\hline LO & 1.0 & & & & & & & \\
\hline MA & $.57^{\star *}$ & 1.0 & & & & & & \\
\hline VI & $.41^{\star *}$ & $.44^{\star *}$ & 1.0 & & & & & \\
\hline AudLing & $.53^{\star *}$ & $.54^{\star \star}$ & $.55^{\star \star}$ & 1.0 & & & & \\
\hline FaLing & $.53^{\star *}$ & $.54^{\star *}$ & $.55^{\star *}$ & $.76^{\star *}$ & 1.0 & & & \\
\hline IS & $.47^{\star *}$ & $.55^{\star \star}$ & $.43^{\star *}$ & $.54^{\star \star}$ & $.53^{\star *}$ & 1.0 & & \\
\hline AP & $.49^{* *}$ & $.30^{* *}$ & $.44^{\star *}$ & $.53^{\star *}$ & $.65^{* *}$ & $.43^{* *}$ & 1.0 & \\
\hline COG & $.59^{\star \star}$ & $.84^{\star *}$ & $.55^{\star *}$ & $.62^{* *}$ & $.60^{* *}$ & $.78^{* *}$ & $.45^{\star *}$ & 1.0 \\
\hline
\end{tabular}

The highest correlation coefficients are between the Cognition and Manipulative scales and between the Cognition and Self-Care Social scales $(.84, p \leq .01 ; .78, p$ $\leq .01$, respectively).

Regarding the five-year-old age group, correlations between the scales showed a different pattern (Table 9).

Table 9

Correlations Between SGS-II's Scales: Age Group of 5 Years' Old

\begin{tabular}{lllllllll}
\hline & LO & MA & VI & AudLing & FaLing & IS & AP & COG \\
\hline LO & 1.0 & & & & & & & \\
MA & .28 & 1.0 & & & & & & \\
VI & -.01 & $.40^{* *}$ & 1.0 & & & & & \\
AudLing & .02 & .28 & $.58^{\star *}$ & 1.0 & & & & \\
FaLing & .03 & .28 & $.44^{* *}$ & $.83^{* *}$ & 1.0 & & & \\
IS & .09 & $.50^{* *}$ & $.39^{* *}$ & $.71^{\star *}$ & $.60^{* *}$ & 1.0 & & \\
AP & .23 & .22 & .24 & $.47^{\star *}$ & $.39^{* *}$ & $.50^{* *}$ & 1.0 & \\
COG & .13 & $.70^{* *}$ & $.47^{* *}$ & $.53^{* *}$ & $.55^{* *}$ & $.82^{* *}$ & $.46^{* *}$ & 1.0 \\
\hline
\end{tabular}

$\mathrm{n}=39$

Note: ${ }^{*} \mathrm{p} \leq .05^{* *} \mathrm{p} \leq .01$

The Locomotor scale did not correlate significantly with the other scales. All other correlations were significant. 


\section{DISCUSSION}

The original UK version of the SGS-II showed internal consistency results ranging from "inadequate" for the Passive Posture scale (0.61) to "good" for the Active Posture Scale (0.88) and "excellent" for all other scales, considering the criteria for the assessment of this type of instrument (European Federation of Psychologists' Associations, 2013). In regard to the result for the Passive Posture scale, the authors explained that this result might have to do with the narrow age range and the small number of items. Our results revealed that all the scales of the Portuguese version of the SGS-II have consistency coefficients, as calculated with Cronbach's alpha that ranged from adequate to excellent. These results are in line with those of the original UK version (Bellman et al., 2012). The only exception was the Passive Posture scale, in which Portuguese internal consistency results were higher than the original version. The higher consistency results obtained in the current investigation might have to do with the fact that the mean results of the Portuguese sample were lower than the results of the UK version (4.52 and 8.93, respectively), and the standard deviation was higher (2.62 and .40, respectively); thus, the range of results in the Portuguese sample is higher, affecting the consistency results. With regard to the standard error of measurement, both the Portuguese and the UK versions have low results, suggesting that both provide reliable results, considering that there is a low degree of measurement error associated with the results obtained with the administration of the instruments.

Regarding correlations between scales, the Portuguese adaptation results are, overall, similar to those of the original UK version for the whole sample, that is, positive and statistically significant. This means that if a child has a high score in a scale, it is likely that the results in another area will also be high. Analysing the correlation results for each of the age groups, it can be inferred that, as the child grows older, the correlations are lower. This might happen because the older children are, the higher their scores in each of the scales will be and the more likely it is that they will reach the maximum scores (Bellman et al., 2012). Furthermore, these results suggest that, if the first years of life are highly dependent on neurological development, over time, the different areas start to become independent of each other (Bellman et al., 2012). Throughout life, stimuli from the environment and through the socialization process increasingly affect development and might contribute to this higher independence among different areas.

One of the limitations of this study is the restriction of the sample to the children that are followed in health units of the Child Health Surveillance consultation, setting out all the remaining children that are followed in private health services. 


\section{FINAL REMARKS}

The Portuguese version of SGS-II revealed a good internal consistency and reliability. Regarding correlations between scales, overall these are similar to the original version. These results suggest that the Portuguese version of SGS-II can be a useful tool in the formal screening of Portuguese children, whether it is used in the context of child surveillance or in paediatrics' consultation, day-care centres or day nurseries. It is hoped that the tools can be useful in the early identification of children with development delays or disorders, allowing early intervention programs adapted to the child's specific needs and environment.

\section{REFERENCES}

Anderson, L., Shinn C., Fullilove, M., Scrimshaw, S., Fielding, J., Normand, J., Carande-Kulis, V. \& Task Force on Community Preventive Services (2003). The effectiveness of early childhood development programs: A systematic review. American Journal of Preventive Medicine, 24(3 Suppl), 32-46. doi: 10.1016/S0749-3797(02)00655-4

Bellman, M., Lingam, S., \& Aukett, A. (1996). Schedule of Growing Skills II: User's guide (2 ${ }^{\text {nd }}$ ed.) Windsor: NFER: Nelson Publishing Company Ltd.

Bellman, M., Lingam, S., \& Aukett, A. (2012). Schedule of Growing Skills II: Escala de avaliação das competências no desenvolvimento infantil II - Dos 0 aos 5 anos - Manual do utilizador (3. ${ }^{a}$ ed.). Lisboa: CEGOC-TEA.

Clayden, G., \& Lissauer, T. (2007). Illustrated textbook of paediatrics. US: Mosby/Elsevier.

Committee on Children with Disabilities (2001). Developmental surveillance and screening of infants and young children. Pediatrics, 108(1), 192-195. doi: 10.1542/peds.108.1.192

Direção-Geral da Saúde. (2013). Programa Nacional de Saúde Infantil e Juvenil. Direção-Geral da Saúde Lisboa.

Early Head Start National Resource Center (2001). Developmental screening assessment and evaluation: Key elements for individualizing curricula in early head start programs. Technical Assistance Paper, No. 4, 1-24. Retrieved from https://www.zerotothree.org/resources/70-developmental-screening-assessment-and-evaluation-key-elements-for-individualizing-curricula-in-early-head-start-programs\#downloads

European Federation of Psychologists' Associations (Ed.). (2013). EFPA Review model for the description and evaluation of psychological and educational tests: Test review form and notes for reviewers. Version 4.2.6.

Fonseca, V. (2005). Desenvolvimento psicomotor e aprendizagem. Lisboa: Âncora Editora.

Frankenburg W., Dodds J., Archer P., Bresnick B., Maschka P., \& Edelman N. (1990). Denver II: Technical manual and training manual. Denver: Denver Developmental Materials.

LaRosa, A., \& Glascoe, F. (2009). Developmental behavioural surveillance and screening in primary care. Retrieved from http://www.uptodate.com/contents/developmental-behavioral-surveillance-and-screening-in-primary-care 
Matos, P. (2009). Perturbações do desenvolvimento infantil: Conceitos gerais. Revista Portuguesa de Medicina Geral e Familiar, 25(6), 669-676. Retrieved from http://www.rpmgf.pt/ojs/index. php/rpmgf/article/view/10693

Sand, N., Silverstein, M., Glascoe, F., Gupta, V., Tonniges, T., \& O'Connor, K. (2005). Pediatricians'reported practices regarding developmental screening: Do guidelines work? Do they help? Pediatrics 116(1): 174-179.

Shevell, M., Ashwal, S., Donley, D., Flint, J., Gingold, M., Hirtz, D., ... Sheth, R. (2003). Practice parameter - Evaluation of the child with global developmental delay: Report of the Quality Standards Subcommittee of the American Academy of Neurology and The Practice Committee of the Child Neurology Society. Neurology, 60, 367-380. Consultado em https://pedclerk.bsd. uchicago.edu/sites/pedclerk.uchicago.edu/files/uploads/neuro.pdf

UNESCO. (2006). Universal declaration on bioethics and human rights. Retrieved on September 4, 2011, from http://unesdoc.unesco.org/images/0014/001461/146180E.pdf 